\section{Drought or Mechanical Stress Affects Broccoli Transplant Growth and Establishment but Not Yield}

\author{
Joyce G. Latimer ${ }^{1}$ \\ Department of Horticulture, Georgia Experiment Station, University of \\ Georgia, Griffin, GA 30223
}

Additional index words. Brassica oleraceae Group Italica, thigmic stress, brushing, wind stress, drought stress, conditioning

\begin{abstract}
Broccoli (Brassica oleracea L. Group Italica Cv. Green Duke) seedlings were subjected to brushing with a piece of cardboard (40 strokes/min, 1 min twice daily), wind $\left(7 \mathrm{~m} \cdot \mathrm{s}^{-1}\right.$ for $5 \mathrm{~min}$ twice daily) or drought (visible wilt for 2 hours daily) treatments. Plant response to treatment was affected by seasonal or environmental conditions. All conditioning treatments reduced leaf dry weight and area, stem dry weight and length, and the total shoot and root dry weights in an experiment conducted in Sept. 1986 (Fall 1986). However, in experiments conducted the following year, broccoli transplants treated in March (Spring 1987) showed little response to the treatments, while transplants treated in August (Fall 1987) showed only a moderate response. In Fall 1986 and 1987, brushing improved field establishment as measured by the rate of shoot dry weight gain over the period of field establishment. Yield of the primary head of broccoli transplants treated in either Spring or Fall 1987 was not affected by the conditioning treatments. Brushing may provide an effective alternative to drought or plant growth retardants in conditioning broccoli transplants prior to field planting.
\end{abstract}

The goal of plant conditioning is to produce sturdy plants that have a high level of photosynthetic reserves and are capable of rapid establishment and resumption of growth in the field (McKee, 1981). The growth of greenhouse-grown transplants has commonly been controlled with plant growth retardants such as daminozide (B-Nine, Uniroyal Chemical Co., Middlebury, Corm.). The recent loss of labeling of daminozide for food crops has seriously affected production practices with respect to height control and conditioning of vegetable transplants. Drought stress, a common hardening treatment, may decrease photosynthetic rates, delay flowering, and increase endogenous inhibitors if treatment is prolonged or severe (McKee, 1981; Rubatzky, 1986). Mechanical stress has been proposed as an alternative conditioning treatment for vegetable transplants because it has improved physical stem strength and stress tolerance in some species, particularly with greenhouse-grown, containerized plants (Biddington, 1985). Brushing is used as a conditioning treatment in commercial production of sugar beet transplants by most of the growers in Japan (Y. Shimamoto, personal communication; Fletcher, 1984).

Stem rubbing or flexing in common bean or eggplant (Jaffe, 1973; Latimer et al., 1986), brushing of cauliflower, lettuce, or celery seedlings (Biddington and Dearman, 1985a), or shaking of tomato (Mitchell et al., 1975) reduces plant growth in both mass and di-

Received for publication 27 Dec. 1989. The cost of publishing this paper was defrayed in part by the payment of page charges. Under postal regulations, this paper therefore must be hereby marked advertisement solely to indicate this fact.

'Assistant Professor. mensions. Wind action also reduces stem length and leaf area (Whitehead, 1957), due in part to the mechanical disturbance (Grace et al., 1982). Shaking increases stem and petiole strength of tomato seedlings (Heuchert et al., 1983) and stem rubbing increases stem strength of common bean plants (Jaffe et al., 1984). Wind treatment reduces the height and "spindliness" of tomato transplants grown at high densities (Liptay, 1985). Brushing improves the appearance and compactness of cauliflower, celery, and lettuce seedlings, but each species responded differently to the treatment (Biddington and Dearman, 1985a). Mechanical stress also delays reproductive development in pea and tomato (Akers and Mitchell, 1984, 1985) and reduces tuber weight of potato (Akers and Mitchell, 1985).

Any conditioning treatment must be examined for long-term effects on crop yield before it can be recommended for use. Therefore, this study examines the effect of brushing, wind, and drought, applied as conditioning treatments during transplant production, on broccoli seedling growth in the greenhouse, subsequent field establishment of the transplants, and final crop yield.

Experimental methods and materials. 'Green Duke' broccoli seeds were sown, three per cell, in plastic cell-packs (cell dimensions, $3.8 \times 3.8 \times 6.0 \mathrm{~cm})$ containing a peat/pine-bark medium (Metro-Mix 300, Grace Horticultural Products, Cambridge, Mass.). Selecting for uniformity in height and leaf area, the seedlings were thinned to one per cell. The resulting plant density was 485 plants $/ \mathrm{m}^{2}$. Seedlings were watered with liquid fertilizer at $200 \mathrm{ppm} \mathrm{N}$ (Peter's 20N$20 \mathrm{P}-20 \mathrm{~K})$ twice per week beginning after seedling emergence.
Treatments were initiated 2 to 3 weeks after seeding, when the second true leaf was beginning to expand, and continued until transplanting (Table 1). One flat of 72 plants was assigned to each of four treatments in a randomized complete-block design with four replications. Mechanical stress was applied twice daily (0830 $\mathrm{HR}$ and $1630 \mathrm{HR}$ ) as a thigmic treatment or as a wind stress. The thigmic treatment consisted of brushing the tops of the seedlings with a piece of cardboard for 1.0 rein, 40 strokes (back and forth). The wind stress consisted of placing the flat of plants in front of a fan to apply an air flow at a rate of $7 \mathrm{~m} \cdot \mathrm{s}^{-1}$ as measured at the edge of the flat nearest the fan. Wind stress was applied for $5 \mathrm{~min}$ (2.5 $\mathrm{min}$ to each lengthwise side of the flat). Control plants were not intentionally disturbed. A drought treatment was included to simulate common bedding plant production, whereby water was withheld early in the day until the seedlings had exhibited visible wilt symptoms for 2 to $4 \mathrm{hr}$ daily in the Fall 1986 experiment or up to $2 \mathrm{hr}$ daily in subsequent experiments. All plants were watered in the late afternoon to prevent drought stress during the night. Control, brushed, and wind-stressed plants were maintained in well-watered condition by watering twice daily.

Mechanical stress and drought treatments were similar for all three experiments, although growing conditions and field preparation dictated that the duration of conditioning ranged from 16 to 28 days (Table 1). Before transplanting, six plants per treatment were sampled randomly from the center portion of each flat in each of the four blocks for determination of leaf area (LI-COR 3000 leaf area meter, LI-COR, Lincoln, Neb.), stem length, and dry weights (after drying for 72 $\mathrm{hr}$ at $70 \mathrm{C}$ in a forced-air oven) of leaves, stems, petioles, and roots (obtained by handwashing from the medium).

An additional 40 plants from each flat were randomly selected for transplanting to the field $30 \mathrm{~cm}$ apart in rows $90 \mathrm{~cm}$ apart. The randomized complete-block design was maintained in the field. The plants were watered by sprinkler irrigation as necessary in 1986 and daily in the 1987 experiments (based on pan evaporation values, Table 1) to prevent excessive drought stress. The field was fertilized in April of each year with $900 \mathrm{~kg} \cdot \mathrm{ha}^{-1}$ of $13 \mathrm{~N}-5.8 \mathrm{P}-11 \mathrm{~K}$, and plants were sidedressed with $50 \mathrm{~kg} \cdot \mathrm{ha}^{-1}$ of ammonium nitrate 4 weeks after transplanting. At selected times after transplanting, six plants per treatment were collected from each block for determination of shoot dry weight gain during field establishment. In the Spring 1987 experiment, a 10-plant section of row in each treatment of each block was selected for harvest data, while 20 plants per treatment were harvested in the Fall 1987 experiment. Total yield is reported as the mean fresh weight of the primary head including $\approx 12 \mathrm{~cm}$ of stalk, as for fresh-market production. Data were subjected to analysis of variance and regression analysis using the general linear models procedure of SAS (Freund et al., 1986).

Transplant growth. Broccoli seedling 
Table 1. Treatment periods, mean daily PAR and maximum/minimum air temperatures in the greenhouse during broccoli transplant production and air and soil (5 $\mathrm{cm}$ depth) temperatures, and pan evaporation during the time period defined for field establishment during three experiments.

\begin{tabular}{|c|c|c|c|c|c|c|c|c|}
\hline \multirow{3}{*}{$\begin{array}{l}\text { Experiment } \\
\text { (date sown) }\end{array}$} & & & \multicolumn{2}{|c|}{ Greenhouse } & \multicolumn{4}{|c|}{ Field establishment } \\
\hline & \multicolumn{2}{|c|}{$\begin{array}{l}\text { Treatment } \\
(\mathrm{DAS})^{2}\end{array}$} & \multirow{2}{*}{$\begin{array}{c}\mathrm{PAR}^{y} \\
\left(\mu \mathrm{mol} \cdot \mathrm{m}^{-2} \cdot \mathrm{day}^{-1}\right)\end{array}$} & \multirow{2}{*}{$\begin{array}{c}\text { Air temp } \\
\left({ }^{\circ} \mathrm{C}, \text { day/night }\right)\end{array}$} & \multirow{2}{*}{$\begin{array}{l}\text { Time } \\
\text { period } \\
(\mathrm{DAT})^{x}\end{array}$} & \multicolumn{2}{|c|}{$\begin{array}{c}\text { Temperature } \\
\left({ }^{\circ} \mathrm{C}, \text { day/night }\right) \\
\end{array}$} & \multirow{2}{*}{$\begin{array}{c}\text { Pan } \\
\text { evaporation } \\
(\mathrm{mm})\end{array}$} \\
\hline & Begin & $\overline{\text { End }}$ & & & & Air & Soil & \\
\hline \multicolumn{9}{|l|}{ Fall 1986} \\
\hline (12 Sept.) & 22 & 44 & 17.0 & $26 / 16$ & 8 & $19 / 7$ & $17 / 14$ & 2.5 \\
\hline \multicolumn{9}{|l|}{ Spring 1987} \\
\hline (4 Mar.) & 12 & 40 & 18.1 & $27 / 15$ & 21 & $26 / 11$ & $24 / 15$ & 6.1 \\
\hline \multicolumn{9}{|l|}{ Fall 1987} \\
\hline (16 July) & 18 & 34 & $12.0^{\mathrm{w}}$ & $30 / 20$ & 14 & $32 / 19$ & $28 / 24$ & 6.6 \\
\hline
\end{tabular}

${ }^{2}$ DAS $=$ Days after sowing.

${ }^{y} \mathrm{PAR}=$ Photosynthetically active radiation.

${ }^{\mathrm{x}} \mathrm{DAT}=$ Days after transplanting.

"Greenhouse shaded, $45 \%$ full sunlight.

Table 2. Effect of mechanical stress or drought on growth of broccoli seedlings during three experiments in a greenhouse.

\begin{tabular}{|c|c|c|c|c|c|c|c|}
\hline Treatment & $\begin{array}{l}\text { Leaf } \\
\text { area } \\
\left(\mathrm{cm}^{2}\right)\end{array}$ & $\begin{array}{l}\text { Stem } \\
\text { length } \\
(\mathrm{cm})\end{array}$ & $\begin{array}{c}\text { Leaf } \\
\text { dry wt } \\
(\mathrm{mg})\end{array}$ & $\begin{array}{c}\text { Stem } \\
\text { dry wt } \\
(\mathrm{mg})\end{array}$ & $\begin{array}{l}\text { Root } \\
\text { dry wt } \\
(\mathrm{mg})\end{array}$ & $\begin{array}{l}\text { Shoot } \\
\text { dry wt } \\
(\mathrm{mg})\end{array}$ & $\begin{array}{l}\text { Root : } \\
\text { shoot } \\
\text { ratio }\end{array}$ \\
\hline \multicolumn{8}{|l|}{ Fall 1986} \\
\hline Untreated & $87.2 \mathrm{a}^{2}$ & $9.8 \mathrm{a}$ & $311 \mathrm{a}$ & $134 \mathrm{a}$ & $175 \mathrm{a}$ & $524 \mathrm{a}$ & $0.34 \mathrm{~b}$ \\
\hline Wind & $75.2 \mathrm{~b}$ & $8.6 \mathrm{~b}$ & $266 \mathrm{~b}$ & $110 \mathrm{~b}$ & $144 \mathrm{~b}$ & $443 \mathrm{~b}$ & $0.33 \mathrm{~b}$ \\
\hline Brushing & $68.3 \mathrm{c}$ & $8.0 \mathrm{c}$ & $237 \mathrm{bc}$ & $101 \mathrm{~b}$ & $144 \mathrm{~b}$ & $397 \mathrm{~b}$ & $0.36 \mathrm{a}$ \\
\hline Drought & $43.8 \mathrm{~d}$ & $6.8 \mathrm{~d}$ & 206 c & $75 \mathrm{c}$ & $93 \mathrm{c}$ & $327 \mathrm{c}$ & $0.29 \mathrm{c}$ \\
\hline \multicolumn{8}{|l|}{ Spring 1987} \\
\hline Untreated & 93.3 & 10.6 & $364 \mathrm{a}$ & 180 & 148 a & 657 & $0.23 \mathrm{a}$ \\
\hline Wind & 84.0 & 10.6 & $311 \mathrm{ab}$ & 168 & $130 \mathrm{ab}$ & 574 & $0.22 \mathrm{a}$ \\
\hline Brushing & 86.0 & 10.6 & $295 \mathrm{~b}$ & 163 & $122 \mathrm{ab}$ & 547 & $0.22 \mathrm{a}$ \\
\hline \multirow[t]{2}{*}{ Drought } & 93.3 & 10.8 & $329 \mathrm{ab}$ & 163 & $108 \mathrm{~b}$ & 599 & $0.18 \mathrm{~b}$ \\
\hline & NS & NS & & NS & & NS & \\
\hline \multicolumn{8}{|l|}{ Fall 1987} \\
\hline Untreated & $62.4 \mathrm{a}$ & $11.5 \mathrm{~b}$ & $177 \mathrm{a}$ & $114 \mathrm{ab}$ & $81 \mathrm{a}$ & $334 \mathrm{a}$ & $0.24 \mathrm{~b}$ \\
\hline Wind & $57.9 \mathrm{a}$ & $11.8 \mathrm{ab}$ & $155 \mathrm{~b}$ & $122 \mathrm{a}$ & $73 \mathrm{a}$ & $310 \mathrm{a}$ & $0.24 \mathrm{~b}$ \\
\hline Brushing & $50.5 \mathrm{~b}$ & $12.3 \mathrm{a}$ & $133 \mathrm{c}$ & $104 \mathrm{~b}$ & $60 \mathrm{~b}$ & $269 \mathrm{~b}$ & $0.22 \mathrm{~b}$ \\
\hline Drought & $59.4 \mathrm{a}$ & $10.6 \mathrm{C}$ & $166 \mathrm{ab}$ & $108 \mathrm{ab}$ & $82 \mathrm{a}$ & $312 \mathrm{a}$ & $0.27 \mathrm{a}$ \\
\hline
\end{tabular}

${ }^{2}$ Mean separation within columns within experiment by least significant difference, $P<0.05$.

${ }^{\text {Ns }}$ Nonsignificant at $P=0.05$.

Table 3. Regression equations describing shoot dry weight as a function of days after transplanting (DAT).

\begin{tabular}{|c|c|c|}
\hline Treatment & Regression equation $^{2}$ & $R^{2}$ \\
\hline \multicolumn{3}{|l|}{ Fall 1986} \\
\hline Untreated & $\mathrm{LSHDW}^{\mathrm{y}}=2.71$ & 0.39 \\
\hline Wind & LSHDW $=2.64 * * *$ & 0.56 \\
\hline Brushing & LSHDW $=2.59 * * *$ & 0.56 \\
\hline Drought & LSHDW $=2.50 * * *$ & 0.38 \\
\hline \multicolumn{3}{|l|}{ Spring 1987.} \\
\hline Untreated & LSHDW $=2.78$ & 0.92 \\
\hline Wind & LSHDW $=2.69 * *$ & 0.91 \\
\hline Brushing & LSHDW $=2.72 *$ & 0.91 \\
\hline Drought & LSHDW $=2.75^{\mathrm{NS}}$ & 0.89 \\
\hline \multicolumn{3}{|l|}{ Fall 1987} \\
\hline Untreated & LSHDW $=2.52$ & 0.95 \\
\hline Wind & LSHDW $=2.48^{\mathrm{NS}}+0.060 \mathrm{x}^{\mathrm{NS}}$ & 0.95 \\
\hline Brushing & LSHDW $=2.41 * * *+0.068 x^{*}$ & 0.94 \\
\hline Drought & LSHDW $=2.49^{\mathrm{NS}}+0.060 \mathrm{x}^{\mathrm{NS}}$ & 0.97 \\
\hline
\end{tabular}

${ }^{2}$ Coefficients tested against those of untreated plants, $t$ test.

${ }^{y}$ LSHDW is the log-transformed shoot dry wt $(\mathrm{mg}) ; \mathrm{x}=\mathrm{DAT}$.

Nonsignificant at $P=0.05$ or significant at $P<0.05,0.01$, or 0.001 , respectively.

growth was reduced by all treatments in the greenhouse, as compared to the untreated plants, during the Fall 1986 experiment but showed less response in the Spring and Fall 1987 experiments (Table 2). In the Fall 1986 experiment, wind and brushing reduced the dry weight of plant parts similarly, but brushing caused a greater reduction in leaf area and stem length. Liptay (1985) reported a $34 \%$ reduction in tomato transplant dry weight after treatment with an air current of unspecified velocity. I observed similar reductions in broccoli shoot dry weight in the Fall 1986 experiment. Drought stress caused the greatest reduction in growth, as indicated by leaf area, stem length, and plant dry weight.

Consistent with previous reports (Akers and Mitchell, 1984; Heuchert and Mitchell, 1983), plant responses to mechanical stress appeared to vary with the season of treatment (Table 2). Although the brushing and wind treatments were applied at the same intensity in all three experiments, they caused less reduction in plant growth in Spring and Fall 1987 than m Fall 1986. Greenhouse environmental conditions were very similar in Fall 1986 and Spring 1987, although treatment duration differed (Table 1). In addition, the treatments caused fewer differences in plant growth during the Spring 1987 than the Fall 1987 experiment. Neither the current data nor those in the literature explain the effect of season on plant response to mechanical stress. The reduction of the drought stress period from 4 to $2 \mathrm{hr}$ reduced the growth response in the 1987 experiments.

Mild drought generally affects root dry weight less than shoot dry weight, resulting in an increase in the root : shoot dry weight ratio (Watts et al., 1981). However, in both the Fall 1986 and Spring 1987 experiments, the root : shoot ratio was decreased by the drought treatment relative to the untreated control (Table 2). Perhaps this was due to more severe drought stress with the larger plants in the limited volume of the root cell compartment. In Fall 1987, drought did not significantly affect either root or shoot dry weight compared to control, but did cause a $12 \%$ increase in the dry weight ratio. Mechanical stress affects the partitioning of dry weight differently in different species (Biddington, 1985; Latimer et al., 1986). In the current study, only brushing in the Fall 1986 experiment increased the root : shoot ratio of broccoli seedlings relative to untreated control plants. Treatment effects may have been insufficient to affect this ratio in the subsequent experiments.

Field establishment. A regression model based on shoot dry weight gain during the period following transplanting was used to estimate treatment effects on field establishment (Table 3). In this model, lower intercept values correspond to lower initial dry weights at transplanting. Larger coefficients 
Table 4. Effect of treatments on broccoli yield and remaining plant fresh weight under field conditions in 1987. The spring crop was harvested twice weekly 29 May (43 DAT) to 12 June ( $=40)$ and the fall crop twice weekly from 9 (51 DAT) to 30 Oct. $(n=80)$.

\begin{tabular}{lcccc}
\hline \hline & \multicolumn{2}{c}{ Spring crop } & \multicolumn{2}{c}{ Fall crop } \\
\cline { 2 - 3 } \cline { 5 - 5 } Treatment & $\begin{array}{c}\text { Yield } \\
(\mathrm{g} / \text { head })\end{array}$ & $\begin{array}{c}\text { Plant fresh wt } \\
(\mathrm{g} / \mathrm{plant})\end{array}$ & $\begin{array}{c}\text { Yield } \\
(\mathrm{g} / \mathrm{h} \text { )ad })\end{array}$ & $\begin{array}{c}\text { Plant fresh wt } \\
(\mathrm{g} / \mathrm{plant})\end{array}$ \\
\hline Untreated & 119 & $519 \mathrm{c}^{2}$ & 240 & 1300 \\
Wind & 138 & $720 \mathrm{a}$ & 222 & 1330 \\
Brushing & 136 & $621 \mathrm{~b}$ & 226 & 1530 \\
Drought & 124 & $597 \mathrm{~b}$ & 234 & 1300 \\
& $\mathrm{NS}$ & & NS & NS \\
\hline
\end{tabular}

${ }^{\mathrm{z}}$ Mean separation by least significant difference, $P<0.05$

${ }^{\mathrm{Ns}}$ Nonsignificant.

for the time variable (DAT) indicate higher rates of gain in shoot dry weight, i.e., faster reestablishment and growth. In Fall 1986, only brushing improved field establishment during the first 8 days after transplanting. Field conditions placed little stress on the transplants during the establishment period in Fall 1986 (Table 1).

Field establishment was not improved by any stress treatment in Spring 1987 where shoot samples were collected from the field 7 and 21 days after transplanting (Table 3). Environmental conditions included high pan evaporation but moderate temperatures (Table I), so that frequent watering maintained the transplants under relatively stress-free conditions. In Fall 1987, field establishment in the first 14 days after transplanting was significantly improved by brushing but not by wind or drought (Table 3). This establishment period corresponded with high temperatures and high pan evaporation (Table 1), placing the transplants under more stress than in the previous experiments. Brushing actually decreased drought resistance of lettuce, celery, and cauliflower seedlings (Biddington and Dearman, 1985b), but stem rubbing increased drought resistance of common bean (Suge, 1980). I have not determined the effect of mechanical stress on the drought resistance of broccoli transplants.

The goal of plant conditioning is to influence plant growth under controlled conditions in a manner that does not reduce the growth potential of the plant. Mechanical stress exerts a temporary effect on plant growth, resulting in an accelerated growth rate within 3 days after the cessation of treatment (Mitchell et al., 1975). This compensatory growth as a result of brushing occurred in Fall 1986 and 1987 as an improvement in field establishment (Table 3). Liptay (1985) stated that wind-treated tomato seedlings established rapidly in the field, finding no differences in plant dry weights after 3 weeks in the field. However, he did not point out that the initial dry weight of the treated transplants was $34 \%$ less than that of untreated plants. Conditioning treatments that improve field establishment would be advantageous for the production of many transplanted crops, especially if proven under controlled-stress conditions. However, the point that' conditioning treatments do not delay field establishment under relatively stress-free conditions is also important in defining new methods of chemical-free growth control practices.

Crop yield. The conditioning treatments had no effect on total yield of broccoli under field conditions in 1987 or on the remaining plant fresh weight in the Fall 1987 experiment (Table 4). In the Spring 1987 experiment, plant fresh weight was greater in all treated plants than in the controls. Head weight and plant fresh weight were smaller in the spring than in the fall, perhaps due to high air temperatures (average maximum 31C) during the spring harvest period. High temperatures near harvest appeared to cause a high frequency of unmarketable heads in the spring experiment, but no treatment effect on the incidence of culls emerged in Fall 1987 (data not presented).

Few studies have examined the effects of mechanical stress on crop yield. Akers and Mitchell (1985) reported that shaking of tomato" plants for $>50$ days delayed reproductive development. Buitelaar (1989) reported yield reductions in tomato in response to daily crop shaking. Short periods (10 days) of brushing have been reported to reduce early, but not total, yield of tomato transplants planted in a cold (9C) greenhouse (Pardossi et al., 1988). The current study used a moderate treatment time and the short harvest period did not allow an assessment of treatment effects on early yield.

Although mechanical stress effects varied between the seasons, it shows promise as a conditioning treatment for broccoli transplants. Seedlings appeared more sturdy and compact even in the Spring and Fall 1987 experiments, where treatment effects on plant growth were less prominent than in Fall 1986. Brushing led to faster post-transplant reestablishment in two experiments. No conditioning treatments affected yields in these studies. Since plant growth retardants are no longer labeled for use on vegetables, brushing may soon become useful for growth control of vegetable transplants. Combining mechanical stress with a mild drought treatment may further improve transplant conditioning and field establishment provided that the combined treatment does not result in a decrease in crop yield.

\section{Literature Cited}

Akers, S.W. and C.A. Mitchell. 1984. Seismic stress effects on vegetative and reproductive development of 'Alaska' pea. Can. J. Bet. 62:2011-2015
Akers, S.W. and C.A. Mitchell. 1985. Seismic stress effects on reproductive structures of tomato, potato, and marigold. HortScience 20:684 686.

Biddington, N.L. 1985. A review of mechanically induced stress in plants. Scientific Hort. 36:1220.

Biddington, N.L. and A.S. Dearman. 1985a. The effect of mechanically induced stress on the growth of cauliflower, lettuce and celery seedlings. Ann. Bet. 55:109-119.

Biddington, N.L. and A.S. Deannan. 1985b. The effects of mechanically induced stress on water loss and drought resistance in lettuce, cauliflower and celery seedlings. Ann. Bot. 56:795802.

Buitelaar, K. 1989. Tomatoes. Plant movement can lead to a lower yield. Groenten en Fruit 44(29):31. [Hort. Abstr. 59(9):7515. 1989.]

Fletcher, B. 1984. Sugar beet growing in Japan. Brit. Sugar Beet Rev. 52(4):8-10.

Freund, R.J., R.C. Littell, and KC. Spector. 1986. SAS system for linear models. SAS Institute, Inc. Cary, N.C.

Grace, J., C.E.R. Pitcairn, G. Russell, and M. Dixon. 1982. The effects of shaking on the growth and water relations of Festuca arundinacea Schreb. Ann. Bot. 49:217-225.

Heuchert, J.C. and C.A. Mitchell. 1983. Inhibition of shoot growth in greenhouse-grown tomato by periodic gyratory shaking. J. Amer. Soc. Hort. Sci. 108:795-800.

Heuchert, J.C., J.S. Marks, and C.A. Mitchell. 1983. Strengthening of tomato shoots by gyratory shaking. J. Amer. Soc. Hort. Sci. 108:801805.

Jaffe, M.J. 1973. Thigmomorphogenesis: the response of plant growth and development to mechanical stimulation. Planta 114:143-157.

Jaffe, M. J., F.W. Telewski, and P.W. Cooke. 1984. Thigmomorphogenesis: on the mechanical properties of mechanically perturbed bean planta. Physiol. Plant. 62:73-78.

Latimer, J. G., T. Pappas, and C.A. Mitchell. 1986. Growth responses of eggplant and soybean seedlings to mechanical stress in greenhouse and outdoor environments. J. Amer. Soc. Hort. Sci. 111:694-698.

Liptay, A. 1985. Reduction of spindliness of tomato transplants grown at high densities. Can. J. Plant Sci. 65:797-801.

McKee, J.M.T. 1981. Physiological aspects of transplanting vegetables and other crops. II. Methods used to improve transplant establishment. Hort. Abstr. 51:355-368

Mitchell, C.A., C.J. Severson, J.A. Wott, and P.A. Hammer. 1975. Seismomorphogenenic regulation of plant growth. J. Amer. Soc. Hort. Sci. 100:161-165.

Pardossi, A., F. Tognoni, and S.S. Lovemore. 1988. The effect of different hardening treatments on tomato seedling growth, chilling resistance and crop production in cold greenhouse. Acta Hort. 229:371-378.

Rubatzky, V. 1986. Safeguard transplants. Amer. Veg. Grower 34:46-48.

Suge, H. 1980. Dehydration and drought resistance in Phaseolus vulgaris as affected by mechanical stress. Rpt. Inst. Agr. Res., Tohoku Univ. Sendai, Japan. 31:1-10.

Watts, S., J.L. Rodriguez, S.E. Evans, and W.J. Davies. 1981. Root and shoot growth of plants treated with abscisic acid. Ann. Bet. 47:595602 .

Whitehead, F.H. 1957. Wind as a factor in plant growth, p. 84-95. In: J.P. Hudson (cd.). Control of the plant environment. Butterworth Scientific, London. 